\title{
Local distribution of blackfly (Diptera, Simuliidae) larvae in two adjacent streams: the role of water current velocity in the diversity of blackfly larvae
}

\author{
Ronaldo Figueiró ${ }^{1,2,3 *}$, Érika Silva do Nascimento ${ }^{1}$, Leonardo Henrique Gil-Azevedo ${ }^{1}$, \\ Marilza Maia-Herzog ${ }^{1} \&$ Ricardo Ferreira Monteiro ${ }^{2}$
}

\begin{abstract}
${ }^{1}$ Laboratório de Simulídeos e Oncocercose, Referência Nacional em Simulídeos, Oncocercose e Mansonelose, Instituto Oswaldo Cruz, Fundação Oswaldo Cruz, Avenida Brasil, 4365, Manguinhos, 21045-900 Rio de Janeiro-RJ, Brasil.

${ }^{2}$ Laboratório de Ecologia de Insetos, Departamento de Ecologia, Instituto de Biologia, Universidade Federal do Rio de Janeiro, Av. Brigadeiro Trompowski, s/n. CCS, IB, Ilha do Fundão 21941-590 Rio de Janeiro-RJ, Brasil.

${ }^{3}$ Programa de Pós-Graduação em Ecologia (PPGE), Universidade Federal do Rio de Janeiro, Brasil.
\end{abstract}

\begin{abstract}
Local distribution of blackfly (Diptera, Simuliidae) larvae on two adjacent streams: The role of water current velocity in the diversity of blackfly larvae. This study aimed to evaluate the influence of water velocity speed on the local distribution and taxocenosis structure of blackfly larvae. The larvae were collected from two adjacent streams located in the municipality of Angra dos Reis (RJ): Caputera River and one of its tributaries. Riffle litter patches were sampled randomly using a 30 x $30 \mathrm{~cm}$ quadrat. Four blackfly species were found: Simulium incrustatum s. $l$. Lutz, 1910; Simulium (Inaequalium) sp.; Simulium pertinax s. l. Kollar, 1832 and Simulium subpallidum s. l. Lutz, 1909. Among these species, Simulium pertinax s. $l$. was clearly associated with higher water current speeds, while Simulium subpallidum s. $l$. showed association with lower water velocities, and Simulium (Inaequalium) sp. had a relatively constant distribution along the water current gradient.
\end{abstract}

KEYWORDS. Co-occurrence; diversity; Neotropical.

RESUMO. Distribuição local de larvas de simulídeos (Diptera, Simuliidae) em dois rios adjacentes: O papel da velocidade da correnteza na diversidade de larvas de simulídeos. Este estudo teve como objetivo avaliar, nos criadouros de simulídeos, a influência da velocidade da água sobre a ocorrência de suas larvas e estrutura de suas taxocenoses. Para obtenção da amostragem foram utilizados "quadrats" de madeira distribuídos aleatoriamente no rio Caputera e um de seus tributários. Foram encontradas quatro espécies: Simulium incrustatum sl. Lutz, 1910; Simulium (Inaequalium) sp.; Simulium pertinax sl. Kollar, 1832 e Simulium subpallidum sl. Lutz 1909. S. (Inaequalium) sp. teve uma distribuição quase constante ao longo do gradiente de correnteza. S. pertinax se mostrou fortemente associada às velocidades mais altas de correnteza, enquanto que $S$. subpallidum se mostrou associado às velocidades mais baixas.

PALAVRAS-CHAVE. Co-ocorrência; diversidade; Neotropical.

Even though blackflies present a worldwide distribution, they can be locally restricted to areas where proper conditions allow the development of their immature forms (Lake \& Burger 1983). One of the most remarkable characteristics of blackfly biology is their potential as colonizers (Kiel et al.1998). Several species are able to colonize substrates in a few hours (Kiel et al. 1998), reaching densities as high as many thousands of individuals per $100 \mathrm{~cm}^{2}$ in a few days (Kiel 1996; Matthaei et al. 1996). However, the densities of blackfly larvae tend to present great fluctuation, high densities being rapidly followed by sudden decreases (Kiel 1996; Matthaei et al. 1996). Several factors are associated to these strong fluctuations of blackfly larvae abundances, such as water speed, food availability and competition (Kiel et al. 1998).

Water flow may change in many aspects, such as speed, turbulence and direction, as a consequence of the complex topography of rivers and streams, which is composed of totally or partially drowned rocks, sticks and aquatic vegetation (Eymann 1993). Due to this variability, and to the fact that certain current types are more suitable to food capture than others (Lacey \& Mulla 1977; Braimah 1987), a given substrate characterized by favorable water flow can be considered a resource (Eymann 1993). This resource can be interpreted as one of the niche dimensions for blackfly larvae. Thus, larvae from different species of blackflies can have evolved adaptations for different water speed ranges as a form of local coexistence. This hypothesis is supported by Palmer and Craig (2000), who proposed a predictive model for the distribution of blackfly larvae along the range of water speeds, based in their labral fan structures.

The present study aimed to test the hypothesis as follows: Do blackfly larvae from different species show different local distributions along the gradient of water speeds in a stream? Some studies relating the occupation of high water velocities as a strategy of predator avoidance for blackfly larvae can be found in literature (Ciborowski \& Craig 1991; Hart \& Merz 1998; Malmqvist \& Sackman 1996; Merz 1991), however, only two studies on the relation between blackfly larvae abundance and water velocity can be found in the literature regarding the neotropical region (Moreira et al. 1994; Santos Jr. et al. 2007). From these mentioned studies, all focus on the effect of water velocity on a single blackfly species, thus, none approaches 
the role of this factor in the structure and composition of blackfly immature taxocenoses, which is evaluated in the current study.

\section{MATERIALAND METHODS}

During March 2005, field sampling was taken in two adjacent streams located in the Angra dos Reis Municipality, Rio de Janeiro State, Brazil. Even though they are neighboring streams, they differ significantly in their physiognomic features. The first, which will be referred to as stream A, is a larger stream with about 15 meter mean width, and as such is more exposed to insolation. On the other hand, the second stream, which will be referred to as stream B, is a tributary of the first river, has mean width of about 5 meters, and a denser canopy cover, which results in more shadowing.

The samples were taken from $30 \times 30 \mathrm{~cm}$ quadrats randomly distributed throughout both streams (one 10 meter section in each stream). As each random quadrat had its riffle litter content sampled, its mean water speed was measured using the head rod method (Wilm \& Storey 1944). Blackfly larvae were separated in morphotypes, and identified in according to their cephalic spots patterns in comparison with mature larvae and pupae previously collected in these localities and species lists regarding that region found in literature (Araújo-Coutinho et al. 1988) and then quantified.

Each stream data was analyzed separately. They had their Shannon diversity index values calculated. As the sampling effort varied randomly for each velocity, mean abundance values were used. Correspondence analyses were performed in order to describe distributional patterns of blackfly larvae, to compare current velocity ranges and to establish their relationships with each other. For the correspondence analyses, data was sorted in four water speed classes.

\section{RESULTS AND DISCUSSION}

Four blackfly species were obtained in the samples from both streams: Simulium pertinax sl. Kollar,1832. Simulium subpallidum sl. Lutz, 1909, Simulium incrustatum sl. Lutz, 1910 and Simulium (Inaequalium) sp.

Blackfly community structure differed remarkably between streams: S. pertinax was the dominant species in both, but the second most abundant species in stream A was $S$. subpallidum, whereas in stream B S.(Inaequalium) sp. was the second most abundant species (Fig. 1). Comparison between the streams using Shannon index showed stream A $\left(\mathrm{H}^{\prime}=0.814715\right)$ as slightly more diverse than stream B $\left(H^{\prime}=0.775942\right)$.

In both streams, there were well defined patterns for the most abundant species (Fig 1a,b), whereas the patterns for the remaining species were unclear. S. pertinax tended to be more abundant in higher water current speeds, whereas $S$. subpallidum seemed to have an opposite pattern, with a trend towards smaller abundances in faster sites. S. (Inaequalium) sp. showed no particular relationship with water current, as well as S. incrustatum.

The correspondence analysis for stream A (Fig. 2) showed
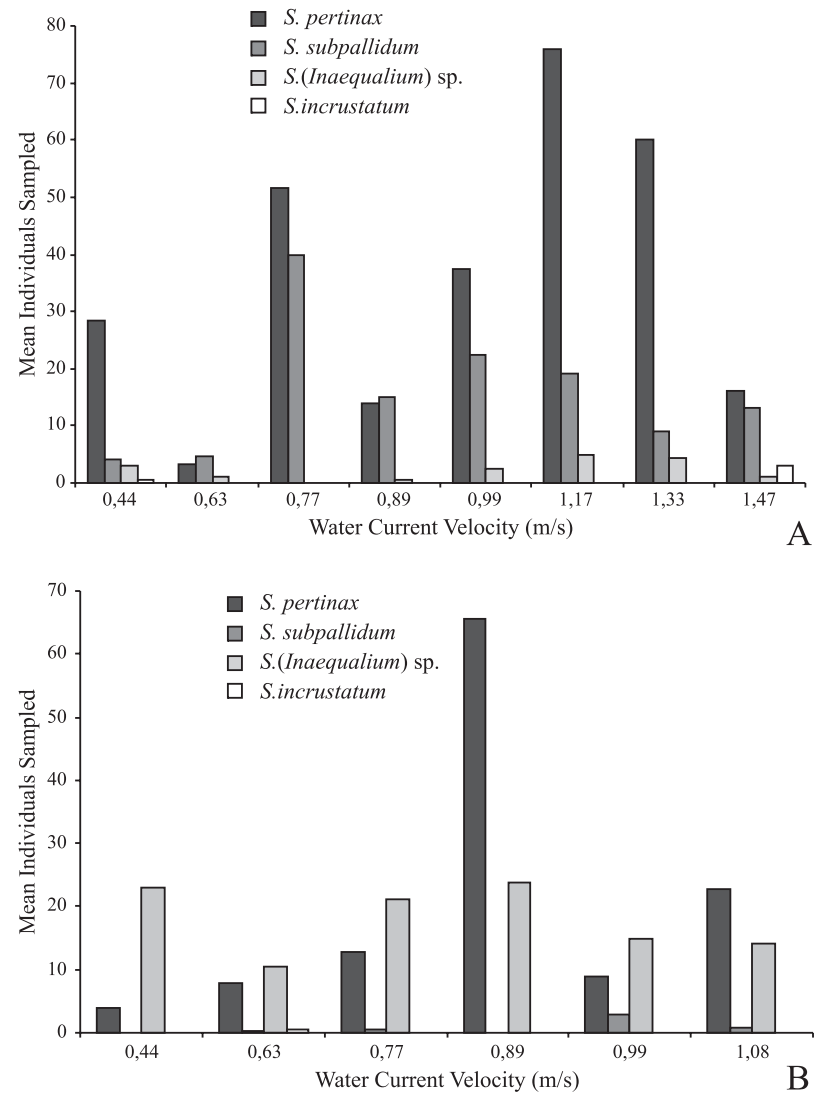

Fig. 1. Blackfly mean abundances within each water current velocity in stream A (A) and B (B).

S. pertinax almost equidistant in the multidimensional space to the third and fourth speed classes $(0.95 \mathrm{~m} / \mathrm{s}$ to $1.21 \mathrm{~m} / \mathrm{s}$ and $1.21 \mathrm{~m} / \mathrm{s}$ to $1.44 \mathrm{~m} / \mathrm{s}$ ), which means its optimal conditions are found somewhere in between these speed classes. On the other hand, S. subpallidum was located closer to the second speed class $(0.70 \mathrm{~m} / \mathrm{s}$ to $0.95 \mathrm{~m} / \mathrm{s})$, indicating that this is its optimal water speed regime. The remaining two species behaved as outliers, probably because of the small number of specimens sampled from them.

In stream B (Fig. 3), however, the correspondence analysis plotted Simulium pertinax closer to the third speed class $(0.76$ $\mathrm{m} / \mathrm{s}$ to $0.92 \mathrm{~m} / \mathrm{s}$ ), and plotted Simulium (Inaequalium) sp. closer to the second water speed class $(0.60 \mathrm{~m} / \mathrm{s}$ to $0.76 \mathrm{~m} / \mathrm{s})$. The remaining species showed unclear associations to the water current speed classes, probably because of their rarity, which didn't allow more detailed analyses.

The dominance of Simulium pertinax in stream A was clear, however, in Stream B there was a light difference to the second most abundant species, $S$. (Inaequalium) sp. The second most abundant species differed from stream A to B. As the correspondence analyses showed, both species seem to have a similar water current speed range (or at least, there is some level of overlap between their speed range associations) as their optimal habitat. This suggests that they are potential competitors for habitat. Thus, it seems that some other factor associated with the river physiognomic features must interfere in the outcome of this competition between these two species. 


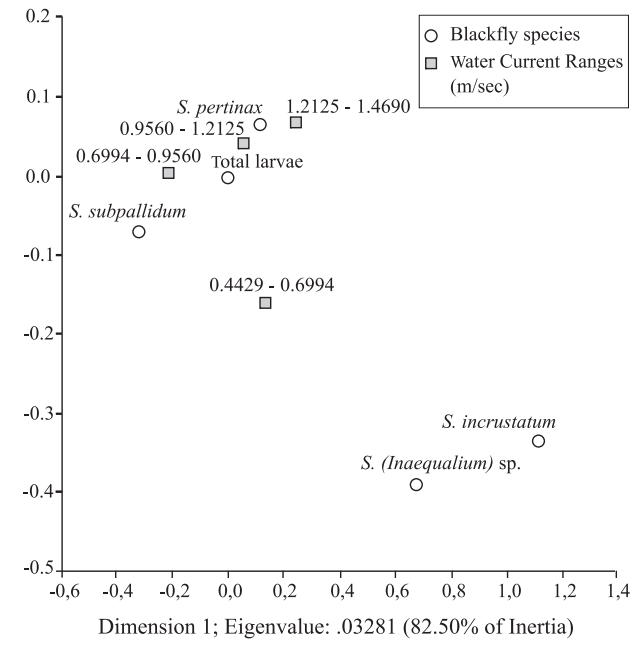

Fig. 2. Correspondence analysis for blackfly species and water current speed classes in stream A.

The role of water velocity variation as a form of habitat heterogeneity, and thus, a diversity generator, seem to be clear in our data: comparing both streams in relation to the length of their water current ranges and their respective diversities, it seems to be a positive relation between these two characteristics. Therefore, we suggest that the wider a water current velocity range is in a stream, the more diverse its blackfly taxocenosis tend to be.

This study shows for the first time comparative patterns of distribution of neotropical blackfly larvae species in relation to water velocity preference. However, due to the scarcity of detailed studies on morphology and foraging behavior of larvae, as well as the role of predators in blackfly population regulation and taxocenoses, further studies should be conducted, in order to identify and describe other important factors influencing local blackfly distribution in conjunction to water velocity, such as predation.

Aknowledgements. To Tatiana Nascimento Docile for the help with field work, Dr. Fernando Fernandez, for the revision of the manuscript, and the staff of Laboratório de Referência Nacional em Simulídeos e Oncocercose / FIOCruz and Laboratório de Ecologia de Insetos / UFRJ for the support. To CNPQ for the research scholarships (RF, LHGA, ESN, RFM).

\section{REFERENCES}

Araújo-Coutinho, C. J. P. C.; M. Maia-Herzog \& B. C. Souza. 1988. Levantamento das espécies do gênero Simulium Latreille (Diptera, Simullidae) no Litoral Norte do Estado de São Paulo. Revista Brasileira de Entomologia 32: 11-17.

Braimah, S. A. 1987. The influence of water velocity on particle capture by the labral fans of larvae of Simulium Malloch (Diptera: Simuliidae). Canadian Journal of Zoology 65: 2395-2399.

Cibrowski, J. J. H. \& D. A. Craig. 1991. Factors influencing dispersion of larval black flies (Diptera: Simuliidae): effects of the presence of an invertebrate predator. Canadian Journal of Zoology 69: $1120-1123$.

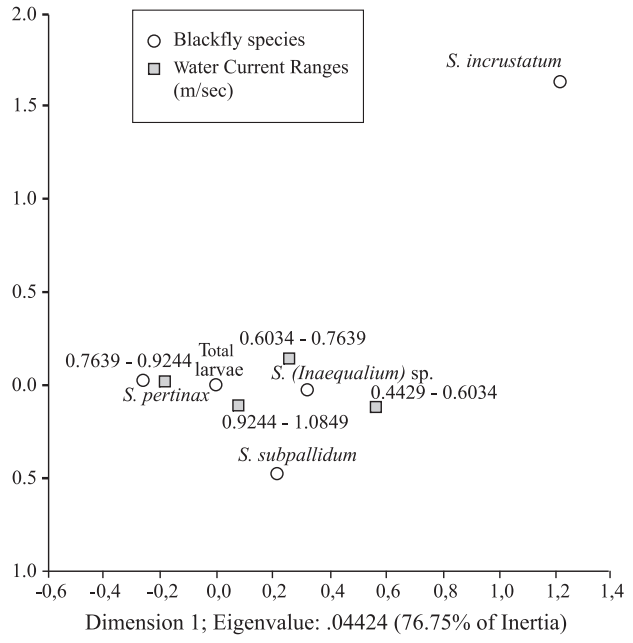

Fig. 3. Correspondence analysis for blackfly species and water current velocity classes in stream B.

Eymann, M. 1993. Some boundary layer characteristics of microhabitats occupied by larval black flies (Diptera: Simuliidae). Hydrobiologia 259: $57-67$.

Hart, D. D. \& R. A. Merz. 1998. Predator-prey interactions in a benthic stream community: a field test of flow-mediated refuges. Oecologia 114: 263-273.

Kiel, E. 1996. Effects of Aufwuchs on colonization by simuliids (Simuliidae, Diptera). International Review der Gesamten Hydrobiology 81: 565-576.

Kiel, E.; F. Böge \& W. Rühm. 1998. Sustained effects of larval blackfly settlement on further substrate colonisers. Archiv fur Hydrobiologie 141: 153-166.

Lacey, L. A. \& M. S. Mulla. 1977. A new bioassay unit for evaluating larvicides against black flies. Journal of Economical Entomology 70: 453-456.

Lake, D. J. \& J. F. Burger. 1983. Larvae distribution and succession of outlet-breedinh blackflies (Diptera: Simuliidae) in New Hampshire, Canadian Journal of Zoology 61: 2519-2533.

Malmqvist, B. \& G. Sackmann. 1996. Changing risk of predation for a filter-feeding insect along a current velocity gradient. Oecologia 108: 450-458.

Matthaei, C.; U. Uehlinger; E. I. Meyer \& A. Frutiger. 1996. Recolonization by benthic invertebrates after experimental disturbance in a Swiss prealpine river. Freshwater Biology 35 233-248.

Merz, R. A. 1991. Flow mediates predator-prey interactions between triclad flatworms and larval black flies. Oikos 60: 187-196

Moreira, G. R. P.; R. A. Pegoraro \& G. Sato. 1994. Influência de fatores abióticos sobre o desenvolvimento de Simulium nogueirai D’Andreatta \& González em um córrego da mata Atlântica. Anais da Sociedade Entomológica do Brasil 23: 525-542.

Palmer, R.W. \& D.A. Craig. 2000. An ecological classification of primary labral fans of filter-feeding blackfly (Diptera: Simuliidae) larvae. Canadian Journal of Zoology 78: 199-21.

Santos-Jr, J. E.; M. N. Strieder; G. L. Fiorentin \& U. G. Neiss. 2007. Velocidade da água e a distribuição de larvas e pupas de Chirostilbia pertinax (Kollar, 1832) (Diptera: Simuliidae) e macroinvertebrados associados. Revista Brasileira de Entomologia 51: 62-66.

Werner, D. \& A. C. Pont. 2003. Dipteran predators of Simuliid blackflies: a worldwide review. Medical and Veterinary Entomology 17: $115-132$.

Wilm, H. G. \& H. C. Storey. 1944. Velocity-head rod calibrated for measuring streamflow. Civil Engineer 14: 475-476. 